Journal of Economics and Behavioral Studies (ISSN: 2220-6140)

Vol. 8, No. 1, pp. 79-86, February 2016

\title{
Effect of Deposit Interest Regional Development Bank, Deposit Interest Rate Government Bank, Inflation, GDP and Money Supply Against Exchange Rate US Dollar
}

\author{
Elsyan Rienette Marlissa \\ University of Cendrawasih Papua, Indonesia \\ elsyan_marlissa@yahoo.com
}

\begin{abstract}
The purpose of this study is to analyze the effect of Deposit Interest Rate Regional Development Bank, Bank Deposit Interest Rate Government, Inflation, Economic Growth (Real GDP), and the money supply of the rupiah per US dollar. The study uses panel data regression analysis with the model Random Effects Model (REM) method and Pooled EGLS (cross section random effects). The results show that factors of interest rate Regional Development Bank, the interest rate on deposits Bank government, the level of inflation, economic growth, money supply have the simultaneous and significant impact on the rupiah per US dollar. While the partial test results show that the interest rate on deposits BPD and the amount of money circulating have a significant negative effect on the rupiah per US dollar. While variable economic growth (GDP) has insignificant negative impact on the rupiah per US dollar.
\end{abstract}

Keywords: Exchange rate of rupiah to US \$, time deposit interest rate, inflationary rate, economic growth, relative money supply, total time deposits

\section{Introduction}

International economic development is rapid, the economic relations between countries will be interlinked and lead to increased trade flows of goods and money and capital between countries. Changes in macro indicators in other countries, will indirectly impact on the indicators of a country. One important factor in the economy that led to the global economy is the currency exchange rate between countries, because every transaction made at this time is calculated by the value of certain currencies such as US dollars. The exchange rate of the currency of a country, especially in determining how much the value of their country's currency required to conduct transactions with other countries. With the use of the US dollar as a means of international exchange as a substitute for the gold standard after the conference Breeton Wood in 1946, then almost all countries make the US dollar as the reference exchange rate of a country that although there are several other currencies, called "Hard Currency" is also used as Pound Sterling, Deuce Mark and Japanese Yen. This will have an impact on international trade because of the value of its currency will fluctuate from time to time so if a sudden change quickly it will belled to exchange rate losses due to the difference in question, including the rupiah. According Lepi (1999: 4) generally causes an economic crisis in Indonesia is not caused due to weak economic fundamentals, but because of the falling value of the rupiah against the US \$. Private foreign debt short term since the early 1990s has accumulated a very large majority of not hedging (hedged against foreign currency). It is then added to the pressure on the rupiah, because there is not enough foreign exchange to pay maturing debt and interest. Table 1 shows development of the rupiah against the US dollar in Indonesia for the period 2005-2008.

Some researches about the factors that influence the exchange rate fluctuations are the economic variables that affect a country's economic fundamentals. These variables include the amount of money supply, interest rates and the level of real output. While Jeff Madura (Arifin, 1989) explains that the factors that influence the exchange rate fluctuations there are three kinds, namely) fundamental factors, related to economic indicators. b) Technical factors, relating to the conditions of demand and supply of foreign exchange. c) The market sentiment factors, associated with rumors of an incidental nature that may affect the fluctuation of foreign exchange rates in the short term. The movement of the rupiah against the US dollar after the policy is applied free floating exchange rate system in Indonesia. The data used are the monthly data started from August 1997 to December 2001. Results of his research, the independent variable that is used have no significant effect on 
the movement of the dependent variable value Exchange Rate, unless variable amount of money in circulation (Adwin, 2002) and several studies about the exchange rate was also conducted by Chiang (1986), Mac Donald \& Taylor (1987), Putnam \& Wodbury (1989), David (1989), Closterman \& Schnatz (2000), Siregar \& Walker (2000), and Drine \& Raulty (2003).

Based on theory and some previous research related to the variables in this study there is a difference that is only use the variable value of time deposits 3 months (quarterly) on the Regional Development Bank in Indonesia and link it with the variable interest rate on deposits futures Regional Development Bank, a variable interest rate time deposits in State Bank (Persero) based on data issued by Bank Indonesia, as well as the variables of economic growth, rate of inflation, money supply and the exchange rate per US dollar. Associated with this background, the authors wanted to see whether the rate of deposit interest Regional Development Bank in Indonesia (RL), Interest Rate Deposit Bank Government (RG), Inflation (INF), Growth (Real GDP) effect positive against rupiah per US dollar (ER), while the money supply (M1) negatively affect rupiah per US dollar (ER) in Bank Indonesia year period 2005-2008.

Table 1: Exchange Rate against USD exchange (in Rupiah)

\begin{tabular}{llll}
\hline Period / Quartal & Exchange Rate ( Rp / USD ) & Growth (\%) \\
\hline 2004 & IV & 9,126 & - \\
2005 & I & & \\
& II & 9,289 & 1.78 \\
& III & 9,548 & 2.78 \\
& IV & 10,006 & 4.80 \\
2006 & I & 9,992 & -0.14 \\
& II & 9,300 & \\
& III & 9,107 & -6.93 \\
& IV & 9,121 & -2.07 \\
2007 & I & 9,134 & 0.16 \\
& II & 9,099 & 0.13 \\
& III & 8,973 & -0.37 \\
& IV & 9,246 & -1.39 \\
2008 & I & 9,234 & 3.04 \\
& II & 9,260 & -0.13 \\
& III & 9,264 & 0.28 \\
& IV & 9,216 & 0.04 \\
\hline
\end{tabular}

\section{Literature Review}

According Sukirno (2004: 402) that changes in supply and demand something currencies, which in turn causes changes in exchange rates, caused by factors such as changes in the taste of the public? Changes in prices of exported and imported goods raise in general prices (inflation), changes tribe interest and the return on investment, economic growth. Adwin (2002) in his study mentioned that the change of GDP that is used does not have a significant effect on the movement of rupiah per US dollar. Nawatmi (2001), the results of the first study could be concluded in the short term, variable real interest rate positive effect on the exchange rate, which means that an increase in the real interest rate would lead to depreciation of the exchange rate, a second study that the long-term, variable the effect on the real exchange rate is the real interest rate with a negative direction. That is if there is an increase in these variables will lead to appreciation of the exchange rate. 


\section{Methodology}

This study use secondary data in the data panel (Pooled-data). As for the observation and measurement period is the time series data (time series) and the cross section for 4 year (quarterly data $=16$ ) in 26 Regional Development Bank throughout Indonesia for the period 2005-2008 with 7 variables. The number of unit analysis are 416 the data (16 x 26 bank), secondary data is sourced from Bank Indonesia (BI and several various reports about amount of deposits of 26 Regional Development Bank in Indonesia. Analysis method is quantitative analysis by using linear regression equation with pooled data which is a combination of time series data with cross section (Gujarati, 2003). The model used by the author in this study refers to the model developed by Adwin (2002). Model for the rupiah as follows:

$$
\begin{aligned}
& \mathrm{ER}=\mathrm{F}(\mathrm{RL}, \mathrm{RG}, \mathrm{INF}, \text { Real GDP, M1) } \\
& \mathrm{ER}_{\mathrm{it}}=\beta_{0}+\beta_{1} \mathrm{RL}_{\mathrm{it}}+\beta_{2} \mathrm{RG}_{\text {it }}+\beta_{3}+\beta_{4} \mathrm{INF}_{\text {it }} \text { Real GDP }_{\mathrm{t}}+\beta_{5} \mathrm{M} 1_{\mathrm{it}}+\varepsilon_{\text {it. . . (1) }}
\end{aligned}
$$

Where: $\mathrm{ER}_{\text {it }}=$ exchange rate rupiah to US dollar period $\mathrm{t}$

$$
\begin{aligned}
& \beta_{0}=\text { Intercept } \\
& \mathrm{RL}_{\text {it }}=\text { deposit interest rate Regional Development Bank of period } \mathrm{t} \\
& \mathrm{RG} \text { it }=\text { deposit rate State Bank of period } \mathrm{t} \\
& \mathrm{INF}_{\text {it }}=\text { inflation rate period } \mathrm{t} \\
& \text { Real GDP Growth period }{ }_{\text {it }}=\mathrm{t} \\
& \mathrm{M} 1_{\text {it }}=\text { Money Supply period } \mathrm{t} \\
& \beta \quad=\text { Coefficient of regression } \\
& \varepsilon \quad=\text { error }
\end{aligned}
$$$$
R G_{\text {it }}=\text { deposit rate State Bank of period } \mathrm{t}
$$

\section{Results and Discussion}

In this experiment, the correlation between independent variables as indicators of the presence or absence of multicollinearity among the independent variables. The test results multicollinearity among the independent variables are described in the following table.

Table 2: Multicolinearity Test for Independent Variable

\begin{tabular}{lllllll}
\hline Korelasi & RL & RG & INF & PDB & MI & ER \\
\hline RL & 1.000 & $\mathbf{0 . 9 7 5}$ & 0.114 & -0.171 & -0.419 & 0.043 \\
RG & $\mathbf{0 . 9 7 5}$ & 1.000 & 0.079 & -0.238 & -0.236 & 0.134 \\
INF & 0.114 & 0.079 & 1.000 & -0.277 & -0.194 & 0.162 \\
PDB & -0.171 & -0.238 & -0.277 & 1.000 & -0.172 & -0.562 \\
MI & -0.419 & -0.236 & -0.194 & -0.172 & 1.000 & 0.106 \\
ER & 0.043 & 0.134 & 0.162 & -0.562 & 0.106 & 1.000 \\
\hline
\end{tabular}

Table 3: Regression Model I for Exchange Rate

\begin{tabular}{lllll}
\hline Variable & Coefficient & Std. Error & t-Statistic & Prob. \\
\hline C & 14951.96 & 2200.733 & 6.794083 & 0.0000 \\
RL & -1840.202 & 729.4884 & -2.522593 & 0.0303 \\
RG & 1407.190 & 579.4185 & 2.428624 & 0.0355 \\
INF & 40.29724 & 105.4348 & 0.382201 & 0.7103 \\
PDB & -95.85677 & 60.74943 & -1.577904 & 0.1457 \\
MI & -0.006944 & 0.002968 & -2.339911 & 0.0413 \\
R-squared & 0.598131 & Mean dependent var & 9425.690 \\
Adjusted R-squared & 0.397196 & S.D. dependent var & 517.4033 \\
S.E. of regression & 401.7143 & Akaike info criterion & 15.10936 \\
Sum squared resid & 1613744. & Schwarz criterion & 15.39908 \\
Log likelihood & -114.8748 & F-statistic & 2.976743 \\
Durbin-Watson stat & 2.260341 & Prob(F- statistic) & 0.066871 \\
\hline
\end{tabular}


Correlation value of the variable interest rate with the Government Bank interest rates Regional Development Bank is close to 1. According Sugiyono (2004: 216), based on guidelines for the interpretation of the correlation coefficient in Table 2. Correlation between 0.80 to 1.00 can be interpreted very strong, so it can be concluded that for the deposit interest rate Development Bank Local $(R L)$ (correlation coefficient $=1.000$ ) were higher than the interest rate on deposits Bank Government $(R G)$ (correlation coefficient $=0.976$ ) which influence the amount of deposits at the Regional Development Banks in Indonesia. Based on the results as shown in Table 3 regression estimation model for exchange rate (ER):

\section{ER=14951,96-1840,202RL+1407,190 RG+40,297 INF-95,85 PDB-0,0069 M1

$\begin{array}{llllll}(6.79) & (-2.52) & (2.43) & (0.38) & (-1.58) & (-2.34)\end{array}$

$\mathrm{R}^{2}=0.5981 ;$ Adj- $\mathrm{R}^{2}=0.3972 ; \mathrm{SE}=401.71 ; \mathrm{DW}$-stat $=2,260$

Model estimates of rupiah per US dollar (ER) above has a value of R-Square of 0.598, which means for 59.8\% change in the exchange rate rupiah per US dollar can be explained by changes in interest rates on deposits of Regional Development Banks, Bank deposit interest rate of the Government, the rate of inflation, economic growth, and the money supply. Based on the results of the estimation parameters in the estimation model rupiah per US dollar (ER), and through testing simultaneously, the results showed that the factor interest rate Bank Government (RG) and the inflation rate (INF), positive and significant effect on the level of significant 5\%, while the deposit interest rates Regional Development Bank (RL), National Economic Growth (GDP), the money supply (M1) was significantly negative effect on a significant level of $5 \%$. The condition was supported by a coefficient of determination (Adj $R^{2}=0.3972$ ) in which the independent variables are able to explain the exchange rate amounted to $39.72 \%$ and the rest is explained by other factors. The interest rate on deposits with BPD has a significant effect negative direction on the rupiah per US dollar. Bank deposit interest rate government significant influence with a positive direction on the rupiah per US dollar variable inflation rate does not affect the positive direction on the rupiah per US dollar. Real GDP is not significantly influenced by the negative direction of the rupiah per US dollar. The money supply influences significantly the negative direction of the rupiah per US dollar.

Factors that influence the exchange rate per US dollar result that the Government Bank deposit interest rates in Partial positive and significant impact on and the rupiah per US dollar. As for variable inflation rate is positive but not significant and the rupiah per US dollar. BPD deposit interest rates and the money supply Partial significant negative effect on and rupiah per US dollar. While variable economic growth (GDP) but no significant negative influence on and rupiah per US dollar. F statistic of $2.977(\mathrm{p}=0.0669)$ can be concluded that the fifth predictors variables in the model above is not significant to estimate exchange rate rupiah per US dollar (ER). That is simultaneously the deposit interest rate Regional Development Bank, Bank deposit interest rate of the Government, the rate of inflation, economic growth, and the money supply did not contribute significantly to exchange rate rupiah per US dollar. Based on the assumption of regression test results, found a very strong correlation between the interest rate on deposits with the Regional Development Bank interest rate government banks (correlation coefficient $=0.976$ ), in order to obtain the best model, one of the two variables must be drop from the model. Since the dependent variable is the exchange rate, the researchers decided to issue a variable interest rate Regional Development Bank model.

Simultaneously factors BPD interest rate, the interest rate on deposits Bank government, inflation, economic growth, the money supply significantly influence rupiah per US dollar. Increased levels of government bank deposit interest and inflation rates as well as a decrease in deposit interest rate of BPD, the money supply and economic growth will boost the exchange rate (depreciated). The model estimates the amount of rupiah per US dollar (ER) above has a value of R-Square (coefficient) of 0.317 which means that only $31.7 \%$ change in the exchange rate rupiah per US dollar (ER) can be explained by changes in interest rates Government bank deposits, inflation, economic growth, and the money supply. F statistic of $1,274(\mathrm{p}=0.338)$ can be concluded that the four variable predictors in the model above is not significant to estimate rupiah per US dollar. That is the simultaneous deposit rates Bank government, inflation, economic growth, and the money supply is not significant in estimating rupiah per US dollar. 
Table 4: Regression Model II for Exchange Rate

\begin{tabular}{lllll}
\hline Variable & Coefficient & Std. Error & t-Statistic & Prob. \\
\hline C & 9545.774 & 878.8126 & 10.86213 & 0.0000 \\
RG & 1.156694 & 51.69291 & 0.022376 & 0.9825 \\
INF & 6.766836 & 161.5094 & 0.041897 & 0.9673 \\
PDB & -120.1589 & 87.92120 & -1.366665 & 0.1990 \\
MI & $8.76 E-05$ & 0.001598 & 0.054832 & 0.9573 \\
R-squared & 0.316578 & Mean dependent var & 9425.690 \\
Adjusted R-squared & 0.068060 & S.D. dependent var & 517.4033 \\
S.E. of regression & 499.4858 & Akaike info criterion & 15.51534 \\
Sum squared resid & 2744346. & Schwarz criterion & 15.75678 \\
Log likelihood & -119.1227 & F-statistic & 1.273866 \\
Durbin-Watson stat & 1.240191 & Prob(F- statistic) & 0.337853 \\
\hline
\end{tabular}

Based on the regression results as shown in Table 4 can be formed a new model for estimation of the exchange rate (ER) as follows.

$$
\begin{aligned}
& \mathrm{ER}=\text { 9545.774 + 1.157RG + 6.767 INF - 120.159 GDP + 0.0000876 M1 } \\
& \begin{array}{lllll}
(10.86) & (0.02) \quad(0,042) & (-1.37) & (0,055)
\end{array}
\end{aligned}
$$

$\mathrm{R}^{2}=0.3167 ;$ Adj $\mathrm{R}^{2}=0.0681 ; \mathrm{SE}=499.4858 ; \mathrm{DW}$-stat $=1.240191$

Influence of Interest Rate Government Bank: The results in model estimation II can be seen that the regression coefficients were obtained for the variable interest rate government banks (RG) of 1.1567 indicates that the interest rate of government banks contributed positively (proportional) to the exchange rate rupiah per US dollar. Bank interest rate increase of one per cent predicted the government will make the rupiah against the US dollar depreciated by 1.1567 rupiah assuming other independent variables unchanged. Statistical test results conclude deposit interest rate the government bank does not have a significant influence $(p>0,05)$ on the exchange rate rupiah per US dollar.

Hypothesis: Bank Deposit Interest Rate Government (RG) positive effect on exchange rate rupiah per US dollar (ER).

Effect of Inflation: The results of model estimation II can be seen that the regression coefficient variable inflation rate (INF) of 6.767 showed the inflation rate contributed positively (proportional) to the exchange rate rupiah per US dollar. The increase in the inflation rate by one percent predicted to make exchange rate rupiah per US dollar depreciated by 6.767 rupiah assuming other independent variables unchanged. Statistical test results conclude the inflation rate does not significantly influence $(p>0,05)$ the exchange rate rupiah per US dollar.

Hypothesis: Inflation rate (INF) positive effect on exchange rate rupiah per US dollar (ER).

Effect of National Economic Growth: The results of model estimation II can be seen that the regression coefficient variable national economic growth (GDP) amounted to -120.159 showed economic growth regions contributed negatively (inversely) to the exchange rate rupiah per US dollars. The increase in national economic growth by one percent is predicted to make the rupiah against the US dollar appreciated by 120.159 rupiah assuming other independent variables unchanged. Statistical test results concluded national economic growth does not significantly influence $(p>0,05)$ the exchange rate.

Hypothesis: Economic Growth (Real GDP) positively affects on exchange rate rupiah per US dollar (ER).

Effect of Money Supply: The results of model estimation II can be seen that the regression coefficient of variable of money supply (M1) amounted to 0.0000876 showed money supply contributed positively (proportional) to the exchange rate, The increase in the money supply amounted to one billion rupiah is predicted to make rupiah per US dollar depreciated by 0.0000876 rupiah assuming other independent 
variables unchanged. Statistical test results conclude the money supply does not significantly influence $(p>0,05)$ the exchange rate rupiah per US dollar.

Hypothesis: The money supply (M1) has a negative effect on exchange rate rupiah per US dollar (ER)

The Economic Meaning and Implications: Results of the estimated average rupiah per US dollar, using the National Economic growth (GDP) showed the same value that is Rp 9425.69. The test results of the panel regression model estimation data for the model number of deposits obtained the test results in partial coefficients with t-test showed that the growth of the national economy (GDP) and money supply (M1) a negative effect. While the deposit interest rate Regional Development Bank (RL), the deposit interest rate Bank Government (RG), the rate of inflation (INF) does not affect the exchange rate rupiah per US dollar.

Deposit interest rate Government Bank: Bank deposit interest rate Government (RG) positive effect on rupiah per US dollar (ER). The results of this study support the hypothesis that the deposit interest rate Regional Development Bank has positive influence on rupiah per US dollar, by looking at the results of statistical tests conclude the deposit interest rate State Bank has significant impact on the exchange rate rupiah per US dollar ( ER). Post estimation results, it turns out the deposit rate and rupiah per US dollar (ER) have the relationship is positive, this means that the theoretical consistency can be proved empirically. From the estimation results obtained that the variable interest rates on deposits in the State Bank has a positive sign towards rupiah per US dollar, it has no meaning if the interest rate goes up, then the rupiah / US \$ will rise.

The estimation results are the same as the results of research conducted by Chiang (1986), Siregar and Walker (2000), the research results that the effects of shocks in monetary aggregates, ( $\mathrm{r}^{*}$ ) real interest rate on the rer (real exchange rate), can be explained (significantly influenced) by any change in the variance $\left(\mathrm{r}^{*}\right)$ real interest rates. Mollick (2000), the research results stated that the interest rate between Mexico and the United States significantly affect the exchange rate Peso against the US Dollar. Nawatmi (2001), the results of research can be concluded first that the short term, variable real interest rate positive effect on the exchange rate, which means that an increase in the real interest rate would lead to depreciation of the exchange rate. On the contrary, according Adwin (2002), the research results stated that the interest rate that is used does not have a significant effect on the movement of the rupiah against the US dollar after the policy is applied free floating exchange rate system in Indonesia. Nawatmi (2001), the results of research can be concluded that in the long second, the variables that affect the real exchange rate is the real interest rate with a negative direction. That is if there is an increase in these variables will lead to appreciation of the exchange rate.

The level of inflation: Inflation has positive effect (INF) against the exchange rate rupiah per US dollar (ER). The results support the hypothesis by looking at the statistical test results conclude significant effect on the inflation rate rupiah per US dollar, this is indicated by the value of the variable probability inflation rate (0.967) is greater than 5\% error rate. This is in line with research Chiang (1986), the research results show that the rate of inflation is positive influence exchange rate against the United Kingdom, France, West Germany, Italy, the Netherlands, except Canada where the coefficient is negative. Mac Donald and Taylor (1987), the results of research that affects a significant interest rate to exchange rate movements. However, contrary to the Nawatmi research (2001), which can be concluded that in the short term, the variables that influence the exchange rate is the expectation of inflation with negative direction, which means that if there is an increase in these variables will lead to appreciation of the exchange rate. Adwin (2002), the research results stated that the inflation rate which is used does not have a significant effect on the movement of the rupiah against the US dollar after the policy is applied free floating exchange rate system in Indonesia.

National Economic Growth: National Economic Growth (GDP) positive effect on rupiah per US dollar (ER). The results of this study do not support the hypothesis, to see the results of statistical tests concluded national economic growth does not significantly influence the exchange rate rupiah per US dollar, and this is indicated by the value of probability variables national economic growth $(0.199)$ is greater than the error rate of 5\%. Post estimation result is similar to the results of research conducted by Adwin (2002), the research results stated that the change of GDP used does not have a significant effect on the movement of rupiah per US dollar after the policy is applied free floating exchange rate system in Indonesia. Economic growth Pre 
Estimates have a positive relationship is consistent with the hypothesis reinforced by theoretical study, proposed that the national economic growth positively effects rupiah per US dollar, this means that if the National Economic Growth rise, then the exchange rate against the dollar America will rise, and vice versa, this was confirmed by the results found among other previous empirical research Drine and Raulty (2003), the research results that the coefficient of per capita GDP significantly.

The money supply: The money supply (M1) has a negative effect against rupiah per US dollar (ER). The results of this study do not support the hypothesis by looking at the statistical result concluded the money supply significantly influence rupiah per US dollar, this is indicated by the value of the variable probability of the money supply (0.957) is greater than 5\% error rate. Results of post estimates that the amount of money supply (M1) has positive effect against rupiah per US dollar (ER). Post estimation result is similar to the results of research conducted by Mac Donald and Taylor (1987), the results Mac Donald and Taylor that the money supply significant impact on exchange rate movements. Chiang (1986), the results of research that the amount of money circulating positive and significant impact on the exchange rate countries Canada, France, Italy. But not significant for the United Kingdom, the Netherlands and West Germany. The money supply Pre Estimates have a negative relationship is consistent with the hypothesis reinforced by theoretical study, proposed that the money supply negatively affect rupiah per US dollar, this means that if the money supply rises, the exchange rate rupiah per US dollar will go down, and vice versa, this was confirmed by the results found empirical by Adwin (2002), the results Adwin mention that the money supply that is used does not have a significant effect on the movement of the rupiah against the US dollar after the applied policy value system free floating exchange in Indonesia

\section{Conclusion}

Partially that the government bank deposit interest rates have positive and significant impact on the exchange rate rupiah per US dollar. As for the variable rate of inflation but not significant positive effect on the exchange rate rupiah per US dollar. BPD deposit interest rates and the money supply a significant negative effect on the exchange rate rupiah per US dollar. While variable economic growth (GDP) but no significant negative impact on the exchange rate rupiah per US dollar. Simultaneously factors BPD interest rate, the interest rate of government bank deposits, the rate of inflation, economic growth, the money supply effect significant against rupiah per US dollar. Increased levels of government bank deposit interest and inflation rates as well as a decrease in deposit interest rate of BPD, the money supply and economic growth will boost the rupiah (depreciate).

\section{References}

Adwin, S. (2002). Analysis of Exchange Rate Movements Against US Dollar After Sisitem policy The implementation of Free Floating Exchange Rates in Indonesia. Journal of Accounting and Finance, 4 (1), 69-78

Arifin, S. (1989). Effectiveness of Interest Rate Policy in the Context of the Crisis Stabilization Rupiah. Bulletin of Monetary Economics and Banking, 1 (3), UREM Bank Indonesia.

Clostermann, T. \& Schnatz, B. (2000). The Determinants of the Eurodollar Exchange Rates: Synthetic Fundamentals and a Non Existing Currency. Discussion Paper, Economic Research Group of the Deutsche Bundesbank, Frankfurt, Germany.

Chiang, T. C. (1986). Empirical Analysis on the Predictors of the Future Spot. Rates. Journal of Financial Research, 9 (2), 69-83.

David, H. P. (1989). Testing Rational Expectations and Efficiency in the Foreign Exchange Market. Econometrica, 51 (3).

Drine, I. \& Raulty, C. (2003). On The Long run Determinants of Real Exchange Rates For Developing Countries: Evidence from Africa, Latin America and Asia. JEL Classification. Euro Qua, Sarbonne University.

Gujarati, D. N. (2003). Basic Econometric. New York: The McGraw-Hill Companies, Inc.

Lepi, T. T. (1999). In general, the cause of the economic crisis in Indonesia is not caused due to weak economic fundamentals, but because of the falling value of the rupiah against the US \$.

MacDonal, R. \& Taylor, M. P. (1987). Exchange Expectation: a Survey. IMF Staff Paper, 39 (1). 
Mollick, A. (2000). Effects of U.S. Interest Rates on The Real Exchange Rate in Mexico. Economics Bulletin, 3 (6), $1-15$

Nawatmi, S. (2001). Determination of Exchange Rate Through Hybrid Model. Journal of Business and Economics, 2 (1).

Putnam \& Wodbury. (1989). Testing Rational Expectations and Efficiency in the Foreign Exchange Market. Econometrica, 51 (3).

Siregar, Y. \& R. Walker, W. C. (2000). Monetary Shocks and the Fundamental Determinants of the Real Exchange Rate under the Hong Kong Currency Board. Ekonomic Asian Journal, 4 (1).

Sugiyono. (2004). Statics for research. CV Alfabeta seventh printing, Bandung.

Sukirno, S. (2004). Macro Economic Theory Introduction. Third Edition. Rajawali Pers. Jakarta. 